\title{
The Presentation of EIL in Kuwait: Students' Expectations and Needs
}

\author{
Hanan A. Taqi ${ }^{1} \&$ Rahima S. Akbar ${ }^{1}$ \\ ${ }^{1}$ The English Department, College of Basic Education, The Public Authority for Applied Education and Training, \\ Ardhiya, Kuwait \\ Correspondence: Hanan A. Taqi, The English Department The College of Basic Education, Ardhiya, Kuwait. Tel: \\ 965-9608-8100. E-mail: hanan.taqi@gmail.com
}

\author{
Received: February 21, 2015 Accepted: April 2, 2015 Online Published: August 26, 2015 \\ doi:10.5539/ies.v8n9p14 \\ URL: http://dx.doi.org/10.5539/ies.v8n9p14
}

\begin{abstract}
The teaching of native-like accents has been the aim of many EFL educationists long ago; however, this concept is heading towards a major change. Hence, the idea of this paper is based on Jenkins' (2000 \& 2002) theory of English as an International Language (EIL). Jenkins' theory analyses the use of English by non-natives speakers (NNS) where the interlocutor is also a NNS; and hence designs a Lingua Franca Core (LFC), that she proposes as a foundation of EIL courses. This study attempted to apply LFC in an EIL classroom in the College of Basic Education in Kuwait, with English major students who are either taking part in a conversation class or a phonetics class. The researcher first selected parts of LFC applicable in the Kuwaiti context, in terms of consonants, vowels, word/syllable stress and connected speech. This choice was based on six hours interaction with both groups. The students were given a questionnaire investigating students' preferences and reflection of the use of Kuwaiti-English exercise tapes and had a group in-class discussion. After the analysis of the questionnaire feedback, the author found that the majority of students would prefer to be exposed to RP or GA, yet be free to use their own Kuwaiti-English dialect. The author later proposes a method of working with the students' abilities and preferences.
\end{abstract}

Keywords: EFL/ESL, native speaker, accent, English, pronunciation, EIL

\section{Introduction}

\subsection{Significance of the Study}

21 st century studies have shown that Received Pronunciation (RP) is spoken by a mere $3 \%$ in the world (Agha, 2007). Strangely, this dialect has been the target dialect of English language teaching for foreign learners (EFL) for decades worldwide. Later, General American (GA) was also added as the "correct English dialect" to be taught in an EFL context. This idea has spread in Kuwaiti public schools as well. Kuwaiti intermediate and secondary public schools taught Oxford textbooks-accompanied by recordings in RP for listening and speaking exercises. In late 1993, the textbooks were changed to locally-designed ones and English was introduced in primary schools; however, the recordings were also in RP. The effect of the accent was later clear in the attitudes towards accents by college students.

14 years ago, when one of the researchers started teaching in Kuwait University, she asked the students to present an oral presentation; the first question she was asked was "in British or American English?" The question at the time was very strange bearing in mind that using an accent is "normally" not a matter of choice at that stage. However, the concept of "accent choice" seemed to be a cultural aspect, where the author found that after a decade she would be asked the same question by a very different group of students. After 10 years, the researcher entered a 'Phonetics and Phonology' class, and asked her students to transcribe one-syllable words such as 'put', 'hat' and 'buy', and she was asked the same question. Usually, every time the researcher was asked that question, the answer was "Speak in an English language I can understand". Yet, the real question was "what is the English that can be understood?" These incidents ignited the search for basic rules that make language "understood". To start the search, one should address the reason the speaker needs to use the language, and the places this language is used.

Most often, people learn a language to communicate internationally, and rarely with native speakers (NS). Most Kuwaitis are interested in learning English to communicate with NNS in restaurants and shops. They also travel around the world, to non-English-speaking countries, and need to use their English (Al-Darwish \& Taqi, 2015). 
In the case of the College of Basic Education (CBE hereafter) English language students, their interest-added to the above mentioned reasons-is to be able to teach the language to primary school students whose L1 is Arabic. All the students in the English Department in CBE are native speakers of Arabic, the majority of which speak the Kuwaiti dialect of Arabic. These students' perceptions of the variation of English dialects were the main goal of this study.

This study was initiated by Jenkins' $(2000,2002)$ idea of encouraging people to speak however they wish, but without jeopardizing intelligibility. This concept was labeled by Jenkins as English as an International Language (EIL), which is concerned mainly with the phonology of English detached from certain dialects and accents. EIL is a language that is based on a Lingua Franca Core (LFC) designed to assure interlocutor understanding, yet, not force speakers to speak a specific dialect. The paper will start at a review of Jenkins idea, where it came from? And how it can be defined?

The aim of this study is to investigate the applicability of Jenkins' LFC principle in light of the students' perception of the theory. To find out whether the proposed EIL theory can be applied in the Kuwaiti context, the author attempted at playing a variety of Arabic-English tapes in class (recorded previously by the CBE students). A questionnaire was distributed to the students after the fifth lecture to investigate the students' reaction towards the clear Arabic accent. The results of the five open-ended questions were analyzed carefully in the light of Jenkins' EIL factors. This was followed by an open in-class discussion for further insight into the issue. The students were also observed during class-speaking sessions, in order to find out whether the seven features of the LFC model could be traced. The study ends with recommendations for teachers of English and Phonology in an EIL environment and for Kuwaiti teachers specifically.

\subsection{Literature Review}

It is a known fact that non-native speakers of English outnumber the native speakers worldwide. This fact has changed the ideologies of educators and English language teachers (Kachru, 1992; Kasper, 1998; Pennycook, 1999, 2000 among many other). Cook (1999, p. 185) proposed a foundation to cope with this phenomenon,

'Language teaching would benefit by paying attention to the L2 users rather than concentrate primarily on the native speaker (and should) apply an L2 user model.'

While so many researchers seem to agree with Cook, the actual attempt at change was not visible in the EFL curricula design, nor within teaching methods and materials. The phonology of English was even less touched by the rise of the number of non-native speakers of English. The language almost entirely used is either RP or GA. It seems to be caged in the native speaker intuition and description.

The spread of English globally is an international phenomenon that has been noticed as early as 1966 by Dickson and Cumming, who in 1996 discovered that English has become the most preferred language by people in Russia. In a survey conducted by Dickson and Cumming (1996), it was found that $60 \%$ of the students in the secondary level chose to study English, as opposed to a mere 25\% who chose German, and 15\% who chose to study French. The desire to learn English is a reflection of "globalization", and an attempt to associate with the rest of the world by speaking a common language (Anchimbe, 2006). In the academic domain, the extensive use of English is evident from the amount of certificates provided in English and the quest of English degrees, in non-English speaking countries. Even journals that have been published in the native language of the publishing country shifted to English publications. An example of this shift was provided by (Graddol, 1997:9) who found that one of the most pronounced medical journals in Mexico Archive de Investigacian Medica that -was published solely in Spanish- started accepting English-written papers, and gradually shifted to publishing all-English papers, while translating Spanish papers into English.

The colonial effect of English use is evident in many countries were English is a Foreign language, such as the case in Russia; and in some post-colonial countries, English is considered the official language. Examples of such countries are India and Singapore, where English has become part of their culture and social identity. From the EFL and ESL domains, it is clear that English "provides a vehicular language for international communication and it forms the basis of constructing cultural identities". Now that the use of English has established a social and cultural importance, the issue of nativity emerged.

\subsubsection{Importance of Native Accents}

To be able to identify accent issues and theories, it is essential to be able to correctly identify the meaning of the term accent. Simpson (1994:3) defines an accent as a "spoken variety of language (that) is realized in speech sounds, and their combinatorial possibilities". Lippi-Green (1997) uses the language distinctions in identifying generations, social class, educational level and ethnicity. He believes that accents are "prosodic and phonemic" 
features that help distinguish geographic and social backgrounds. As accent seems to carry the notion of "class", the choice of a second or foreign accent, when possible, is usually not accidental, but rather a "class" preference.

The preference of an English accent in an ESL and EFL context has been set between two major dialects; namely, Received Pronunciation (RP) and General American (GA). For decades, RP has been considered as one of the most prestigious English dialects (Jenkins, 2000, p. 5). RP is a British dialect associated with prestige. For many decades, RP had been considered the "correct" accent of English. Spoken by a minority, RP held its status as having roots in public schools, spoken by elite Londoners and the Home Counties, and being labeled as the Queen's English. GA, on the other hand, is a US accent, which is common in the north part of the US, mid-western and mid-coast. GA is commonly known as the "network" language, as it is mostly heard in broadcasts and in TV programs. GA has held its prestigious reputation because of its link to academic settings worldwide.

$\mathrm{RP}$ and GA are not what is usually referred to as 'Standard English'. Rather, Standard English is not a certain accent or style of English, it is considered "a purely social dialect...which is distinguished from other dialects of the language by its grammatical forms" (Trudgill, 1999, p. 123). Hence, according to Trudgill (ibid) Standard English might be considered an accent of English, yet it could not be considered a standardized language. Therefore, RP, GA and Standard English are standardized accents of English, and there is not one accent that can be considered the only Standard English accent, but all accents that can be labeled "standard" could also be labeled "native".

The importance of native accents of English in an ESL and EFL environment has been a pressing issue for decades. Tarone (2005) stated that the 'native-like' accents have been the focus of FL teaching for so long, but now its importance is being questioned by educationists and researchers. The importance of 'teaching' an accent is very time consuming. Mckay $(2002$, p. 42$)$ found that teachers not only spent a lot of time teaching an accent, but they also spent a lot of time trying to change their own pronunciation. In their study which involved Austrian university students, Dalton and Puffer (1997) found that the majority of students preferred RP and GA over other non-standard English accents. Later, Macedo (2001) conducted a similar study with Japanese high school students and found that the majority of the participants preferred the 'prestigious' RP accent.

The choice of and bias towards native accents has spread far beyond the walls of schools and colleges, and reached the advertisement sector. A good example of a study related to accents and advertisements was a study conducted by Green et al. (1975) to view the effect of accents on global marketing. They found that the use of accents can solve global problems like learning a language. Anchimbe (2006) noted several German advertisements that stress native-English as being the most important feature of any service. An example provided by Anchimbe (ibid) was a Munich City Bike Tour Company advertisement that states

"Munich City Bike Tour Company is looking for guides/sales staff to round out the 2004 season. Must be native English speaker, high energy, fit and FUN (that's what we sell) seasonal through October, flexible schedule and good pay."

From the advertisement, one could notice that 'native English speaker' is the most important requirement to get the job. Another advertisement put by a German family also stresses that the person who wants to work as a nanny for their children should have a 'Marry Poppins' English.

The native-speaker model seems to spread by the belief that native speakers are perfect in their use of language. The native speaker has been the sole valid judge of correct language, and was expected to identify reasons behind grammatical mistakes (Chomsky, 1965). Until the late 1900s, most linguistic studies based their findings on the judgments of native speakers. Starting from the Transformational-generative grammar, where the native speaker is the 'backbone' of Chomsky's (1965) “ideal-speaker hearer". Van Dijk's (1998) "P-system" in context grammar was built on native speakers, and Brown and Levinson's (1987) "modelperson", in politeness theory, is the native speaker. In addition, Bloomfield (1933) with many other American linguists focused their studies on native-like competence relying on the spontaneous speech of native speakers.

\subsubsection{The Choice of Accents}

The importance of accents lies in the differences between them. Alego (2006, p. 2) stated that 'tune' is the most important difference between American and British English; hence, emphasizing intonation, followed by vowel and consonant pronunciation. The importance of a native -like accent has been gradually fading, bringing in the importance of 'intelligibility'. Anchimbe (2006, p. 6) concludes on the stressing of the use of native accents,

"when more non-native teachers are involved in ELT than native, when English is progressively being detached from the native English-speaking countries, when lesser 
attention is being paid to accent, when the so called non-native speakers of English outnumber the native, that some institutions still run after and are caught by the fever of recruiting only (historical) native-speaking teachers"

However, many studies have shown that some accents are more preferable than others from the viewpoint of students. For example, in their study, Lippi-Green (1997) investigated the accent preference of Dutch learners. They found that the learners labeled the British accent as the 'norm', while the American accent was considered 'dynamic' and 'attractive'. Another study, conducted by Prodromou (1992) investigated the preference of 300 young adult Greek learners from different learning levels, and found that $75 \%$ of the participants preferred to learn British English, as opposed to 18\% who preferred American English. In a study of Spanish students' comprehension abilities in connection to accent, Lopez-Soto and Berrara-Pardo (2007) exposed the students to two varieties of English; General American and Received Pronunciation. They found that $60 \%$ of the students believed that the British accent was 'more correct'.

Although there is a tendency by EFL/ESL educationists to move away from the accent focused classrooms, some studies have shown that accents have an effect on the learning process. Brown's (1968) study investigated the learning of English of Twi and Ewe native speakers. The participants were spoken to in a pure RP accent, and English-Twi accent, and an English-Ewe accent. He found that the Twi participants performed better when spoken to in a Twi-English accent, while the Ewe performed better when spoken to by a Ewe-English speaker. In addition, Wilcox (1987) conducted a similar study on Singaporean learners using four different accents of English: Singaporean, British, American, and Australian. The majority of the participants found the Singaporean accent easier to comprehend. In their study on EFL Iranian students, Moinzadeh et al. (2012) found that most Iranian students benefited from the Iranian accented English rather than RP or GA (refer to other studies in this context to Ekong, 1982; Smith \& Bisazza, 1982; Barlow, 2010; Kovacs \& Racsmany, 2008).

\subsubsection{EIL Context}

As many studies have shown that the use of non-native English accent could be sometimes even more beneficial to students than native English accents, many researchers and scholars found the need for change in the direction of EFL phonology. Macaulay (1988) was one of the first researchers to question the importance of a native-like accent. His idea was based on the fact that only $3 \%$ of the English speakers use RP, yet this particular accent has been considered the target of many EFL phonology classrooms. Macaulay pointed out that some phonological elements of RP seemed to be not only not necessary for learners, but also very time-consuming to attempt to learn. This idea was followed by a suggestion stated by Crystal (1995) to use the standards Scot accent as the EFL model for English learners. Jenkins' (1996, 1997, 1998, 2000, 2002) was one of the most effective educationists in the field of EFL phonology who attempted to identify phonological needs rather than luxury. She demanded a change in priorities when teaching phonology. Jenkins (1998) stressed the notion of 'intelligibility' as the main factor to measure 'good English'. Hence, the EFL speaker could speak however he/she wishes, but without jeopardizing intelligibility. Jenkins called this idea English as an International Language (EIL). EIL is a language that is based on a Lingua Franca Core (LFC) designed to assure interlocutor understanding, yet not force speakers to speak a specific dialect. It also involves the idea of accommodation: adjusting speech to facilitate communication or changing one's speech to make it more intelligible or sometimes congregating one's spoken habits to resemble those of one's speakers (Cogo \& Dewey, 2006, p. 254). Jenkins (2000) believed that "It is a current irony that L2 learners are nowadays the only English speakers who are encouraged to speak RP or GA as closely as possible, while regionally accented (NS) are not discouraged from teaching in their own accent".

Therefore, Jennifer Jenkins attempted to design a new Common Core list of English language features based on a Core previously created by Jenner in 1989. The Common Core designed by Jenner (1989) was an attempt to list several features Jenner found essential to reach intelligibility. In spite of constituting many key features of the English language, Jenner's attempt lacked the 'International' feature of English. Thus, Jenkins' (2000), so as to take the reality of full EIL into account, designed a Lingua Franca Core which identifies 7 areas in which it is essential to eliminate error in our students' pronunciation.

The seven LFC features are as follows:

- Vowel quality: the distinction between long and short vowels is more important than precise vowel quality, and should be clear in speech. (e.g. when sick becomes seek in a Spanish accent of English).

- Consonant conflations: when a consonant of English does not exist in a learner's mother tongue, the 'missing' sound is substituted with something related from the speaker's first language. (Where in Korean round becomes lound.) 
- Phonetic realizations: another strategy used when stressed to pronounce English is to use a sound from your mother tongue that might be close to the required English sound. (e.g. as in Arabic, park is pronounced as bark)

- Consonant cluster simplification: learners practice two profoundly different strategies to deal with consonant clusters. A good example would be 'square', which might be pronounced as siquare or isquare depending on the dialect of Arabic spoken.

- Prominence and weak forms: on the continuum between stress-timed and syllable-timed languages, English, with its various weak-form words and its heavily-reduced unstressed vowels, lies well towards stress-timing (this is a far Asian based feature).

- Tone groups: inadequate use of tone groups to divide the stream of speech into manageable, meaningful chunks has severe effect on intelligibility (as a question might sound like an order).

- Nuclear/contrastive stress (not tone): stressing a particular word in English stresses its importance. This English feature might cause intelligibility issues if stress was misplaced by EFL speakers, as it will send a different meaning.

\subsection{Research Questions}

While the majority of English Language teachers are non-native speakers of English in schools, colleges and universities, for many years, it was believed that RP \& GA should be "taught", especially in phonetics courses. Transcription was always made in RP, regardless of what accent the students were listening to.

According to the literature above, teaching English phonology used to be a very hectic and time consuming job, as reaching a native-like accent is not an easy task. Yet, it appears that the native-like accent should not be the focus of EFL classrooms, instead, the focus should be on intelligibility. This brings us to the main question addressed in this research,

Is Jenkins' (2000, 2002) EIL theory applicable and useful in the Kuwaiti context?

To reach an answer to this question, the following questions were pursued:

- $\quad$ Are the students able to identify the speakers' accents?

- How comfortable are the students with the non-native English accents?

- Do the speakers fully understand different accents they hear?

- Are the students encouraged to use different accents in their class when they become teachers?

\section{Methodology}

\subsection{In-Class Observation Sessions}

The methodology utilized in this study was both qualitative and quantitative. The first was an observation session of the students during two different classes, freshmen students participating in a conversation course as part of the basic skill courses that the English department offers to its students, and a phonology class of senior students during their final year in college in the Spring semester of 2013. The mother tongue of all the students participating is Arabic, as it is the norm in CBE. The data was check-listed in accordance to Jenkins' seven LFC points, with the aim being finding relevance/ differences with the core issues listed in the proposed theory (overviewed in the literature review).

\subsection{Recording Based Questionnaire}

The second method was an implementation of a questionnaire based on recordings of poems done by Kuwaiti, Syrian and Egyptian students in class for two weeks (6 class hours). Ten students (4 Kuwaitis, 3 Syrians, and 3 Egyptians) recorded the poems reflecting emotions and relationships of love, hate, friendship and the like, in accents influenced by their mother tongue. On one hand, the conversation class students listened to the recordings, after which they were placed in groups of 4 to 5 in order to discuss the meanings implied in the poems and its relationship to their own experience. On the other hand, the phonetics students were assigned to phonetically transcribe the same poems using IPA. After two weeks, the students were given a short open-ended questionnaire aiming to investigate the students' perception towards the accent of the speaker who read the poems and the use of a nonnative speaker in an EFL/EIL class. The following is an example of the poems students were exposed to: 


\author{
A Part of My Heart \\ I've made many wishes, \\ I've dreamt many dreams, \\ I've prayed many prayers, \\ I've talked to God, \\ And I've seen, \\ What I thought was love, \\ Come and go.
}

\title{
2.3 In-Class Interviews
}

The questionnaire was further followed by an open in-class discussion to find more specific reflection of the accents they have listened to. Afterwards, the open-ended questionnaires were manually analyzed to obtain statistics to be verified against the students' comments during the open in-class discussions.

\section{Results}

The analysis consists of three parts; the observation, open-ended questionnaire, and the in-class interviews.

\subsection{The Observation}

It is important to mention at this stage, that the classes in the English department are mostly, if not always, monolingual. The participants in both classes all spoke in Arabic as their mother tongue, however, they spoke different dialects of Arabic. Most students spoke a dialect of Kuwaiti-Arabic, some spoke Syrian-Arabic, others spoke Egyptian Arabic, and two students spoke in Lebanese-Arabic. Yet, all the students understood the different Arabic dialects, Kuwaiti-Arabic being the most difficult in vocabulary use.

Once the class starts, the students are instructed to speak in English all the time, yet a specific dialect was never favoured. Nonetheless, the Phonetics and Phonology class normally listen to RP and GA recordings to transcribe the speech phonetically, for which they were required to identify the accent of the speaker. All the recordings prior to the time of this investigation were in a voice of a native-English speaker.

The following was observed during the students' conversations and discussion in class,

- Vowel quality constantly changes in Kuwaiti English (KE). It depends on the dialect of Arabic spoken (i.e. urban or suburban). In some cases, the students seem to depend on the spelling to realize the sound which causes vowel lengthening. A good example of this is the realization of the word 'ship' which is constantly realized as [ $\mathrm{i}: \mathrm{p}]$ where it is assumed that the letter ' $i$ ' is realized as $/ \mathrm{i} /$ no matter where it occurs in a word. On the other hand, vowel shortening appears as a result of hyper-correction, which is very popular in the classroom. An illustration of this phenomenon is the word 'kiwi' which is often realized as [kewi].

- Kuwaitis are ABLE to realize all consonants and vowels of English, with the exception of a few 'consonant clusters'. The consonant cluster/skw/ as in 'square' and /sks/ as in 'excuse' do not exist in Arabic. Hence, the speakers choose to use a very common Arabic phonotactic (a technique to avoid realizing the consonant cluster). The tactic depends on inserting a vowel before or between consonants. Hence, 'square' is pronounced as [sıkweır] or [iskwe Ir].

- Consonants that do not exist in the Arabic inventory are sometimes confused, such as $/ \mathrm{p} / \mathrm{and} / \mathrm{b} /$. If the consonant does not exist in Arabic speakers will either,

$\checkmark \quad$ Use the voiced/voiceless counterpart. Therefore, words with the sound /v/ are realized as /f/ (e.g. [faIv] is realized as [fa $\mathrm{f}]$.

$\checkmark \quad$ Hypercorrect the consonant, where the words that conatin $/ \mathrm{b} /$ or $/ \mathrm{f} /$ are realized with [p] or [v]. For example, the word 'physics' is realized as [vizıks].

- Arabic intonation shares similarities and differences with English (Jong \& Zawaydeh, 1999, p. 20); the differences might cause intelligibility issues, where asking a question might sound like an order based on English intonation.

- Stress does not cause intelligibility problems among same L1 speakers, especially that both Arabic and English are stressed-timed. However, generally speaking, word stress in an Arabic sentence is usually on words with heavy syllables (i.e. are open and closed syllables containing a long vowel). This feature in Arabic stress might be a cause of confusion among native speakers of English, or non-native speakers of Arabic. 


\subsection{Open-Ended Questionnaire}

Keeping the findings of the observation in mind, the students were given six open-ended questions. The questions inquired about the students' attitudes towards different, non-native accents of English. The first question was focused on making sure the recordings were clear, and understood by the students. All the students confirmed that the recordings were clear and they understood the poems well. The quality of the recordings was thus not a barrier. When the students were asked about the speakers' accents, $85 \%$ of the students were able to identify the Kuwaiti speaker. However, only $11 \%$ of the participants were able to identify the other two accents (Syrian and Egyptian) correctly. Many students confused the Syrian accent for the Lebanese; and the Egyptian was, in some cases, believed to be Syrian and Lebanese. $4 \%$ of the participants were not able to identify any speakers' accent, and even assumed some speakers were Italian and Russian!

The students were later asked "Did you like listening to the speakers who had a non-native accent? And why?" Surprisingly, $73 \%$ of the participants did not like the use of non-native accents; they were the same students who identified the Kuwaiti accent correctly. The reasons they gave for their discomfort was that some believed that the Kuwaiti accent did not feel 'serious' and sounded 'strange'. Some people stated that they felt confused when the accent was not 'American and British'. A few participants (9\%) did not mind any accent of English as long as the recordings were clear and the words were understood. When asked why they did not care about the accent, they stated that the information being shared was the important part of the recordings. Two phonetics students felt that different accents added a little challenge to the transcription exercise.

The next question was about the students' preference of native English accents. $77.7 \%$ of the participants stated they preferred a native speaker of English. Most participants specified the native accent as being British or American. The most common reasons behind their choice is (listed from the most common to the least common),

- The American and British accents are preferred because they are the language of TV and Cinema. Some students commented, "We don't watch Kuwaiti-English movies".

- Kuwaiti English is not a common accent of English, so it's very difficult to transcribe.

- It doesn't teach us anything about English phonetics because "It's not English".

- Listening to a native accent provides an English-like environment. As English teachers-to-be, we need to have an environment that is purely English.

- Listening to native-accent recordings allows us to learn the "real" dialects of English, and speak like Americans.

- The native-accent recordings sound professional.

Obviously, the majority of the participating students (77.7\%) indicated that they would not use non-native recordings in their classrooms when they become teachers. They gave a few reasons such as their will to teach their students a native accent because it is more prestigious. Some students felt that it would be easier for the students to understand. One student commented that by playing native-English recordings "the class will be more enjoyable".

The questionnaire answers clearly show that the majority were not in favour of listening to non-native speaker recordings. They also prefer American or British teachers as they have showed a will to learn a native accent.

\subsection{In-Class Interviews}

The instructor started the in-class discussion by asking the students why they wanted to learn English. Most students said that they were interested in learning English to communicate with employees in restaurants and shops. They also travel around the world, to non-English-speaking countries, and need to use their English. Many of them found that mastering the language is fundamental for their future career as English teachers in primary schools.

When the students were asked about what they liked most in the recordings they heard in class, some students, especially those in the Phonetics and Phonology class, stated that they liked the challenge of identifying the speaker's origin. For others, the poems were very interesting; hence, the accent was not a major issue. However, many students did not have much to say about what they liked; rather most of them could say something about what they did not like.

The in-class discussion has also revealed that the students seem appalled by the fact that their accent was labeled 'Kuwaiti-English' or 'Egyptian English'. Many students stated that they never thought of their language in association with their origin or mother tongue. They wanted to be 'good' English speakers, and the labeling did 
not make them feel like good teachers. One student noted that "when the recordings were played, I was shocked!" She did not think that it was possible to use non-native recordings in class.

The words 'strange' and 'professional' had the lead in the discussion. Particularly, in the Phonetics and Phonology class, were students felt the transcription process felt 'awkward'. The Conversation class, on the other hand, indicated that as soon as they heard the first recording, they felt that the classes were not 'professional'. Many students were wondering why these specific recordings were used.

\section{Discussion}

Examination of the students' spoken language in the conversation classes accentuates a number of problems that tend to affect their speech intelligibility. On one hand, vowels of English are amongst such problems, where short vowels are usually lengthened in a pattern that affects intelligibility. A word with a short front vowel such as 'sick', for example, might be pronounced as 'seek', causing a meaning-change context. At a lesser level, long vowels may also be hyper-corrected by using short vowels as in a word like 'hack' being pronounced as /hık/, once again, causing semiotic disturbances.

On the other hand, pronunciation of three consonant clusters is another phonological problem that Kuwaitis, as well as other Arab students face, yet they seem to coop satisfactorily by using a phonotactic of inserting a vowel in between or adding one initially. The problem is therefore posing no noticeable intelligibility barrier.

With the students' lack of a few English consonants such as $[v]$ and $[p]$ in their mother tongue, the students tend to either replace them with their voiced/voiceless counterparts, as in replacing [v] with[f] and [p] with [b],or even hyper-correct them by the overuse of one to replace the other. The two techniques tend to intensely affect their speech intelligibility, particularly as the mentioned phonemes would usually affect meaning.

Intonation and stress are further phonological aspects of our students' language, with both having their own comparative features. Expressing a request by sole reliance on a rising intonation in Arabic tends to feature the students' requests in English (requiring a syntactic order change) in a manner that reflects ordering. This feature requires to be specifically addressed during the teaching of English to students whose mother tongue is Arabic. We therefore suggest the importance of teaching our students intonations associated by various functions of the English language, but more importantly, those that tend to very different in nature from their mother tongue.

The students' responses on the recordings' clarity signals the intelligibility of the presented accents regardless to the heard variety. The finding in this regard indicates that our study informants have unanimously perceived the speeches as completely comprehensible. We must admit at this point that we would never be able to speculate whether any of the varieties might have been perceived as more intelligible when compared to others, specifically since the question has not provided the students with graded responses. Discrepancies on the identification of the accent origins is not surprising at all, due to the fact that English with a Kuwaiti accent (Kuwaiti-English) would normally be widely spread and heard amongst a community of a Kuwaiti majority population. Accents that were less accurately identified have also been misconceived within a very close approximation regions (Lebanon and Syria both being located in extremely close geographical regions). Accordingly, the researchers believe that such a slight misconception would less likely affect the study's findings in regards to the audience's attitudes towards the speech recordings. Having stated that, the finding established a higher 'inter rater reliability' of the recordings, we assert.

When the study informants were asked about their comfort levels after hearing non-native accents, a majority of $70 \%$ seem to have disliked the presented accents, justifiably as being perceived as 'less serious', 'strange', and at a less prominent level, 'confusing'. On the other hand, a staggering less than $10 \%$ only seems to find such non-native English accents as acceptable, due to the fact that, 'they are intelligible'. For such an elite group, intelligibility rather than nativity is what they care about.

When the students were asked about their accent preferences, their responses indicate a high percentage (reaching slightly below $80 \%$ ), who prefer what they referred to as being native accents, describing British/American as being so. The previously-mentioned accents are highly perceived due to a number of reasons, some of which as being 'T.V language, easier to transcribe, provides a native-like environment, a 'real' dialect, and sound 'more professional. The students tend to, therefore, prefer to learn British/American accents.

In-class interviews have been conducted to gain a deeper insight on the issues under the scope of the study. The obtained results on the issue of learners' views on non-native accents, alongside a number of related issues, have revealed a number of findings, which may be summarized as follows:

a. One of the purposes for which students feel the need to learn English is to obtain a level of proficiency that would enable them to successfully communicate in two life venues; foreigner employees in local shops and 
restaurants, and non-English speaking countries. At a much important level, students feel that their expected future career as teachers of English in primary schools necessitates obtaining high proficiency levels in English.

b. The views of the study informants towards hearing non-native English accents tend to vary in accordance to whether they were third/fourth year or freshmen students. While freshmen students found it difficult to accept non-native accents, finding it strange and unprofessional, many of the phonology class students perceive those accents as interesting and posing a challenge for the way they may be transcribed. The finding may press the importance of exposing future English teachers to courses of phonetics and phonology as they may enhance their views of speaking English with intelligible rather than the so-called native British/American speech, particularly, as they will graduate to work in an environment of teaching English to foreigners, whereby they will hear foreign students using the language in a definitely foreigner accent.

Looking back into our study's questions, the present study's findings indicates that the students of the English Department at the College of Basic Education tend to easily identify the various English accents, with each being somewhat accurately associated to the speakers' origins. The students seem to feel less comfortable when they are exposed to accents other than the so called native-like accent (British \& American). Nevertheless, the extent at which they feel uncomfortable needs to be further investigated. The students seem to have a full understanding of the various English accents. However, they are less likely to accept hearing those accents as they believe they will affect their ability to speak 'proper' English in the future. As the students have mostly expressed their strong discomfort and rejection of the 'awkward', 'confusing' accents, they will be more likely to discourage using accents other than the ones they perceive as being native (British \& American).

\section{Conclusion}

This study investigated the applicability of Jenkins' $(2000,2002)$ idea of EIL and the use of LFC to teach English phonology without the tension of teaching a native accent of English in the English Department in the College of Basic Education in Kuwait. Although this study lacks the investigation of various variables that might be useful in terms of accent identification and use, such as age, gender and major, yet the researchers were able to reach several conclusions.

The study has shown that even with LFC pronunciation errors in the speech of students in the two classes under investigation, the students seemed to understand each other, which proves that the need of LFC in monolingual context is not as crucial as it in multilingual environments. It was found that the students' intonation, especially, use of phonotactics with consonant clusters that do not appear in Arabic, and consonant switch occur very often in class, but the students seem to understand each other with no difficulties, and the instructor was able to understand their speech as well.

From the in-class interview with students, the researchers found that the students wanted to speak in their own accent, and accent of English influenced by their Arabic mother tongue, but would like to be exposed to native English. Consequently, most students felt that the phonetic transcription would be done better when students reflect on their own accent of English, yet preferred to transcribe native speech. In this case, the students should be allowed to express themselves freely in their own accent, since they feel comfortable doing so, and the instructor should only interfere when there are LFC features that affect intelligibility.

Teachers need to know the LFC features enable to design exercises that target intelligibility threatening features. This study highly recommends the use of EIL targeted programs. The use of EIL should not cover the entire course syllabus, but it can be used to show students different features of Englishes. It could also encourage them to learn the language aside from attempting to learn a perfect native-like accent. Good examples of teaching EIL would be phonetic practices with $/ \mathrm{v} /, / \mathrm{p} /, / \mathrm{t} \mathrm{S} /$, reading exercises that emphasize intonation and stress, spelling rules and vowel differences in word differentiation, such as sleep versus slip. All of these practices can be simply embedded in the course, and would not be time consuming as accent-teaching.

Most students do not like their language to be identified as Kuwaiti-English, or Egyptian-English, they prefer "English only". There is no harm in respecting their desire, but always showing them that having an accent only makes their language use more unique.

\section{References}

Agha, A. (2007). Language and Social Relations. Cambridge University Press.

Al-Darwish, S., \& Taqi, H. (2015). EFL Presentations: investigating the effect of confidence and experience". International Journal for English Language Teaching, 3(1).

Alego, J. (2006). British or American English: A handbook of word and grammar patterns. Cambridge: 
Cambridge University Press. http://dx.doi.org/10.1017/CBO9780511607240

Anchimbe, E. A. (2006). The native speaker fever in English language teaching (ELT): Pitting pedagogical competence against historical origin. Linguistik Online, 26, 1-6.

Bloomfield, L. (1933). Language. New York: Henry Holt and Company.

Brown, K. (1968). Intelligibility. Language testing symposium: A psycholinguistic approach (Ed. By A. Davies, pp. 180-191). London: O. P. U.

Brown, P., \& S. Levinson (1987). Politeness: Some universals in language usage. Cambridge: Cambridge University Press.

Chomsky, N. (1965). Aspects of the theory of syntax. Cambridge: MA.

Cogo, A., \& Dewey, M. (2006). Efficiency in ELF Communication: From Pragmatic Motives to Lexico-grammatical Innovation. Nordic Journal of English Studies, 5, 2.

Cook, V. (1999). Going beyond the native speaker in Language Teaching. TESOL Quarterly, 33(2), 185-209. http://dx.doi.org/10.2307/3587717

Crystal, D. (1995). The Cambridge Encyclopedia of the English Language. Cambridge University.Press.

Crystal, D. (1997). English as a global language. Cambridge: Cambridge University Press.

Dalton-Puffer, C. (1997). Learners Attitudes and L2 Pronunciation in Austria. World Englishes, 16(1), 115-128. http://dx.doi.org/10.1111/1467-971X.00052

Dickson, P., \& Cumming, A. (Eds.) (1996). Profiles of language education in 25 countries. Slough: NFER.

Ekong, P. (1982). On the use of an indigenous model for teaching English in Nigeria. World Language English, 1(2), 87-92. http://dx.doi.org/10.1111/j.1467-971X.1982.tb00474.x

Graddol, D. (1997). The future of English. The UK: The British Council.

Green, J. M., \& Oxford, R. (1995). A closer look at learning strategies, L2 proficiency, and gender. TESOL Quarterly, 29, 261-297. http://dx.doi.org/10.2307/3587625

Jenkins, J. (1998). Which pronunciation norms and models for English as an International Language? ELT Journal, 52(2), 119-26. http://dx.doi.org/10.1093/elt/52.2.119

Jenkins, J. (2000). The Phonology of English as an International Language. Cambridge University.Press.

Jenkins, J. (2002). A Sociolinguistically Based, Empirically Researched Pronunciation Syllabus for English as an International Language. Applied Linguistics, 23(1), 83-103. http://dx.doi.org/10.1093/applin/23.1.83

Jenner, B. (1989). Teaching pronunciation: The common core. Speak Out! 4, IATEFL.

Lippi-Green, R. (1997). English with an Accent: Language, ideology and identity in the United States. London: Routledge.

Lopez-Soto, T., \& Barrera, P. D. (2007). Perceptions of accents by L2 students of English: Subjective preference vs. objective intelligibility. ICPHS, 1601-1604.

Macaulay, R. (1998). RP RIP. Applied Linguistics, 9(2).

Macedo, D. (2001). Sociolinguistics. Birmingham: University of Birmingham.

McKay, S. L. (2002). Teaching English as an International Language. Oxford: Oxford University Press.

Moinzadeh, A., Rezaei, O., \& Dezhara, S. (2012). The effect of non-native accent on Iranian EFL learners' listening comprehension, focusing on Persian accent of English. Journal of Language Teaching and Research, 3(5), 967-972. http://dx.doi.org/10.4304/jltr.3.5.967-972

Prodromou, L. (1992). What culture? Which culture? Cross-cultural factors in language learning. ELT Journal, 46(1), 39-49. http://dx.doi.org/10.1093/elt/46.1.39

Simpson, J. (1994). Accent. In R. Asher (Ed.), Encyclopedia of language and Linguistics (pp. 8-12). Oxford: Pergamon.

Tarone, E. (2005). Speaking in a second language. In E. Hinkel (Ed.), Handbook of research in second language teaching and learning (pp. 485-502). London.

Trudgill, P. (1999). Standard English: What it isn't. In T. Bex \& R. J. Watts (Eds.).

Van Dijk, T. (1998). Ideology: A Multidisciplinary Approach. London: Sage 
Wiclox, G. K. (1978). The effect of accent on listening comprehension: A Singaporean study. English Language Teaching Journal, 32, 118-127.

\section{Copyrights}

Copyright for this article is retained by the author(s), with first publication rights granted to the journal.

This is an open-access article distributed under the terms and conditions of the Creative Commons Attribution license (http://creativecommons.org/licenses/by/3.0/). 